PUPIL: International Journal of Teaching, Education and Learning

ISSN 2457-0648

Lee E Chai, 2022

Volume 5 Issue 3, pp. 68-82

Received: 06 ${ }^{\text {th }}$ May 2021

Revised: 20 th July 2021, 20 th September 2021, 30 th December 2021

Accepted: 31 ${ }^{\text {st }}$ December 2021

Date of Publication: 07th January 2022

DOI- https://doi.org/10.20319/pijtel.2022.53.6882

This paper can be cited as: Lee, D. P.Y E Chai, T. J. (2022). The Usage of MS Word And JavaScript in ELearning Courseware Development. PUPIL: International Journal of Teaching, Education and Learning, $5(3), 68-82$.

This work is licensed under the Creative Commons Attribution-NonCommercial 4.0 International License. To view a copy of this license, visit http://creativecommons.org/licenses/by-nc/4.0/ or send a letter to Creative Commons, PO Box 1866, Mountain View, CA 94042, USA.

\title{
THE USAGE OF MS WORD AND JAVASCRIPT IN E- LEARNING COURSEWARE DEVELOPMENT
}

\author{
Diana Phooi Yan Lee \\ General Studies Department, Politeknik Sultan Idris Shah, Sungai Lang, 45100 Sungai Ayer \\ Tawar, Selangor, Malaysia \\ dianalpy@psis.edu.my \\ Chai Teck Jung \\ Civil Engineering Department, Politeknik Sultan Idris Shah, Sungai Lang, 45100 Sungai Ayer \\ Tawar, Selangor, Malaysia \\ tjchai@psis.edu.my
}

\begin{abstract}
This paper introduces a new approach that enables a simplified and automated development of interesting and attractive e-learning courseware by using a Java template. This new approach enables the development of better-quality e-learning courseware in less time and at less cost, and without pre-requisite knowledge of complicated software such as Macromedia, FrontPage, and etc. In the development process, Microsoft Word, HTML coding, and JavaScript are used. In this e-learning courseware development, Microsoft Word software is used for content editing and saved as a .html file. The saved.html file will be encoded using JavaScript for the files to be viewed on web browsers such as Internet Explorer or Chrome. Developing, editing and updating are made
\end{abstract}


simple as the developers only need to amend the.doc file through Microsoft Word and save it as a .html file. The JavaScript will automatically generate the link between the doc and html files. This approach has been tested by selected polytechnic lecturers and received positive feedback. The developed e-learning courseware was somehow limited to the functions and features provided by MS Word Software. Therefore, for future study, developers may apply other applications such as Kahoot, Quizizz, etc to make the learning process more engaging and interesting. Overall, this is a user-friendly tool for people or subject matter experts who would like to develop rapid and simple e-learning courseware.

\section{Keywords}

E-Learning, Courseware Development, Microsoft Word, JavaScript, Online Teaching and Learning, Pandemic Covid-19

\section{Introduction}

In the age of digital technologies, there are many ways to improve our education delivery system to engage digital native students or the millennial generation. Hence, the lecturers need to increase their capabilities by teaching in a new way as students nowadays are growing up in a technological environment. Furthermore, with the emergence of the Covid-19 pandemic around the globe nowadays, face-to-face $(\mathrm{F} 2 \mathrm{~F})$ teaching and learning are made harder among lecturers and students. To curb the spread of this new pandemic virus, the Malaysian government has implemented the first Movement Control Order (MCO) in March 2020 and all institutions were to close. Therefore, all lecturers have to shift from face-to-face lessons to online lessons. Thus, lecturers have to create and build their teaching and learning materials or e-learning courseware to cater for this online lesson.

Due to a sudden shift from face-to-face teaching and learning to online teaching and learning, lecturers have to create an interesting and motivating online lesson that would encourage student-centered learning (SCL). However, many lecturers have limited knowledge in using available software or application to create e-learning lessons. Though there are various applications and software available nowadays but many lecturers especially those who are not internet savvy or those with limited IT skills think that it is hard to develop e-learning courseware as they need to have a high level of computer literacy and it requires the use of complicated software such as Author ware. Therefore, this e-learning courseware development approach is 
developed whereby with the use of common software, that is Microsoft Word, lecturers can develop their e-learning courseware.

Microsoft Word (MS Word) as developing by the Microsoft Corporation is one of the common software used by most people around the world and this word processing files are being generated every day as far as documentation is concerned. MS Word is a user-friendly tool and is widely used and highly valued among lecturers for all sorts of documentation purposes such as preparing quizzes, assignments, notes, and much more. In other words, all lecturers regardless of their race, age, or educational background have exposure to the use of MS Word in their daily life and are skillful in using the software. Nowadays, the updated version of MS Word provides many functions and features to ease the users. One of the functions is the 'save as' function which enables users to convert word processing files to Web pages easily, that is, with just a button click of the 'save as' HTML command.

Hence, with this user-friendly function, this paper introduces a new approach to creating e-learning courseware (i.e., web page) by using MS Word with the built-in .jar file (i.e., JavaScript). From the review of literature, Microsoft Word software has been used in a study on lightweight websites development (Hao \& Li, 2017). Another study by Luo (2010) used Hypertext Markup Language (HTML), Cascading Style Sheets (CSS), and JavaScript to implement web pages. Whilst, other studies used different software and application in developing the e-learning courseware, for example, the use of UNICODE (Sadashiv \& Prakash, 2016), Authorware professional (Wolfe, 1992), and Courseware Authoring Validation Information Architecture (CAVIAr) (Melia \& Pahl, 2009) in e-learning development. From the literature review, thus far, there is no study on e-learning courseware development using the combination of Microsoft Word and JavaScript. Thus, this is a new approach that enables educators to easily develop their elearning courseware. The advantage of this approach is it is user-friendly as Jscript files have been coded in advance, hence this enables educators with no coding or programming knowledge to create their e-learning courseware without hassles. Therefore, educators can develop their elearning courseware as long as they know how to use MS Word. It is easy to edit and save the changes by modifying only the .doc file and therefore the developer (i.e., the lecturer or educator) can work fast. Besides that, it is cost-effective as the e-learning developer does not need to spend money on buying Author ware software or application as they just need to use MS Word to develop their e-learning courseware. Moreover, this e-learning development approach is environmentally 
friendly because the development process does not require the use of paper, and the students can easily browse or download the content (i.e., the softcopy) from the website. As Moore et al. (2007) stated, "simple is better and less is more" which indicates that something simple is better than the complicated one and that is the main principle when developing learning or an e-Learning strategy.

\section{Literature Review}

In the innovation era, people or organizations need to continuously improve themselves from different perspectives. Nowadays, more technologies are being developed and used by people for different purposes regardless of their limited knowledge or skills on information technology (IT). With technologies, things are made simple but yet effective and e-learning is one of the strategies used in the education field. With technology, educational capabilities are pushed to a higher level as time pass and it has become an inevitable element in teaching and learning (Jayachitra, 2020). Despite the importance of technology's integration in classroom teaching and learning, Jayachitra (2020) stated that most educators, especially those who are technology immigrants may not fully utilize the educational technology available as compared to the younger generation who are technology natives. However, due to the impact of pandemics, the traditional ways or blended model of teaching and learning are now fully shifted to full reliance on technology. Lecturers or educators, despite the level of education, are now required to conduct the online lessons via the use of different technology and online platforms such as Microsoft Team, WEBEX, Zoom, etc. Hence, e-learning becomes an important element as far as education is concerned.

\subsection{E-Learning}

In the broadest sense, Marriott de Cassia \& Torres (2009) stated that e-learning is an exploration of new approaches to learning something with the support of available information and communication technology (ICT) for face to face teaching and learning (F2F), hybrid, and also distance learning (Marriott de Cassia \& Torres, 2009). The concept of e-learning, as stated by Kpakiko, et al. (2021) is the use of information technology in the process of synchronous and asynchronous teaching and learning, whilst Hoq (2020) briefly defined it as technology-supported education. Meanwhile, Horton \& Horton (2003) stated that e-learning can be defined as the creation of learning experiences with the use of web and internet technologies. There are five types of e-learning (i.e., learner-led e-learning, facilitated e-learning, instructor-led e-learning, 
embedded e-learning and telementoring, and E-coaching) and different types of E-learning require different tools and technologies (Horton \& Horton, 2003).

According to Jayachitra (2020), e-learning is a new and effective learning framework that utilizes the existing technology tools. Jayachitra (2020) further highlighted that technology is merely a tool that aids in pedagogical practices and content delivery whilst educators play an important role in redesigning and creating an engaging lesson. Thus, e-learning courseware plays an essential role as far as online teaching and learning are concerned (Jayachitra, 2020).

\subsection{E-Learning Courseware}

According to Jayachitra (2020), e-learning courseware is an important and effective model of teaching and learning to enhance students' academic achievement. In the past, developing elearning courseware was not an easy task as no authoring tools available. Thus, creating e-learning courseware would require a group of programmers with good IT savvy to do the coding and programming. Besides that, the cost is another factor to be considered as far as e-learning courseware development is concerned. A survey on 34 companies as reported in Technical Horizons in Educational Journal revealed that the cost for authoring software development ranged from as low as $\$ 50$ for microcomputers to as high as $\$ 64000$ for mainframe (Greenfield, 1990 as cited in Wolfe, 1992). Wolfe (1992) highlighted that one of the widely respected authoring systems which are catered for educators, that is, Authorware Professional by Authorware Inc. was sold at about $\$ 8000$.

Nowadays, as technology gets more and more advanced, e-learning courseware development is made simple and more economical as there are varieties of authoring software or application available in the market. Horton \& Horton (2003) stated that authoring and integrating the content are parts of the process of creating e-learning. Thus, the educators, may use the authoring software and integrate the related teaching and learning content to develop their elearning courseware. These authoring tools help to simplify the process of creating e-learning and thus, individuals without extensive technical knowledge would be able to create their e-learning courseware easily (Horton \& Horton, 2003).

Hirumi (2002) stated that the development of e-learning requires new instructional strategies that support an interactive collaborative learning environment. However, many novice teachers face difficulties to plan and managing meaningful e-learning interactions. The teacher might adopt teacher-directed methods which indirectly end up relying heavily on self-instructional 
text or lecture-based materials. Hence, the teacher might fail to promote meaningful interactions among the students, instructor, and content. The factors that lead to this problem are that the teachers have insufficient time, training, and resources which end up forcing teachers or educators to revert to what they know, that is, teacher-directed instructional methods (Donelly \& McSweeney, 2009). Therefore, authoring tools are crucial as it eases educators in developing elearning courseware which in turn encourage meaningful e-learning interactions among the students, teacher, and content.

\section{Significance of Study}

The teaching profession has always been a challenging task for all educators around the globe. The sudden emergence of the pandemic Covid-19 has impacted educators from different parts of the world. For instance, a study on TEFL professors' e-learning experiences by Shaaban (2020) revealed that lack of e-learning knowledge and the technical problem are the obstacles in developing e-learning courses. Though education is now no longer limited to physical classrooms and many e-learning related platforms such as Open Courseware, Massive Open Online Courses (MOOCs), Learning Management Systems (LMS), etc. have been offered and applied by most institutions. However, this arises another challenging task for educators who just started to learn and use these platforms. Therefore, it is important to come out with a new approach to ease the development of e-learning courseware. Thus, this paper aims to introduce a simple way to develop e-learning courseware without any hassle by using a common software that people around the globe are familiar with, that is, Microsoft Word.

\section{Methodology}

The methodology involves was the development of the e-learning courseware. The subject selected for this courseware development was Communicative English which is one of the compulsory subjects in Malaysia's polytechnics. As this is a newly developed e-learning courseware, hence, it is yet to be implemented among the students. The development of this courseware, on the whole, involved two polytechnic lecturers and was assisted by a lecturer from Civil Engineering Department for the JScript coding. The timeframe in completing the e-learning courseware was about two months in total including the stage of planning, Jscript coding, and content development. 
In general, this e-learning courseware was developed through a few stages as shown in Figure 1. The first stage is to select tools for e-learning development. In this e-learning courseware development, JavaScript and Microsoft Word were chosen. Jscript provides a template-based authoring environment, that is, the Content Creator which enables authors to add content directly or import it from PowerPoint, Hypertext Markup Language (HTML) pages, or Microsoft Word (MS Word).

Identifying the content is the second stage and, in this e-learning courseware development, Communicative English was chosen. Next, in the development stage, the e-learning courseware is developed by creating a .doc file by using Microsoft word and JScript Script file will create the link between the .doc file and .html file. The .doc file will be automatically saved as a .html file. The java template which consists of the JScript Script file is used to specify the location of each file, topic, or chapter of the content. The JScript Script can be edited by using notepad. The fourth stage is testing the generation of a .html file in the browser. This stage is to test run the file generated to identify broken links. Finally, the successfully generated file will be uploaded to the website so that students can browse and download the content. The stages of the e-learning courseware development are simplified in the form of a diagram as shown in Figure 1.

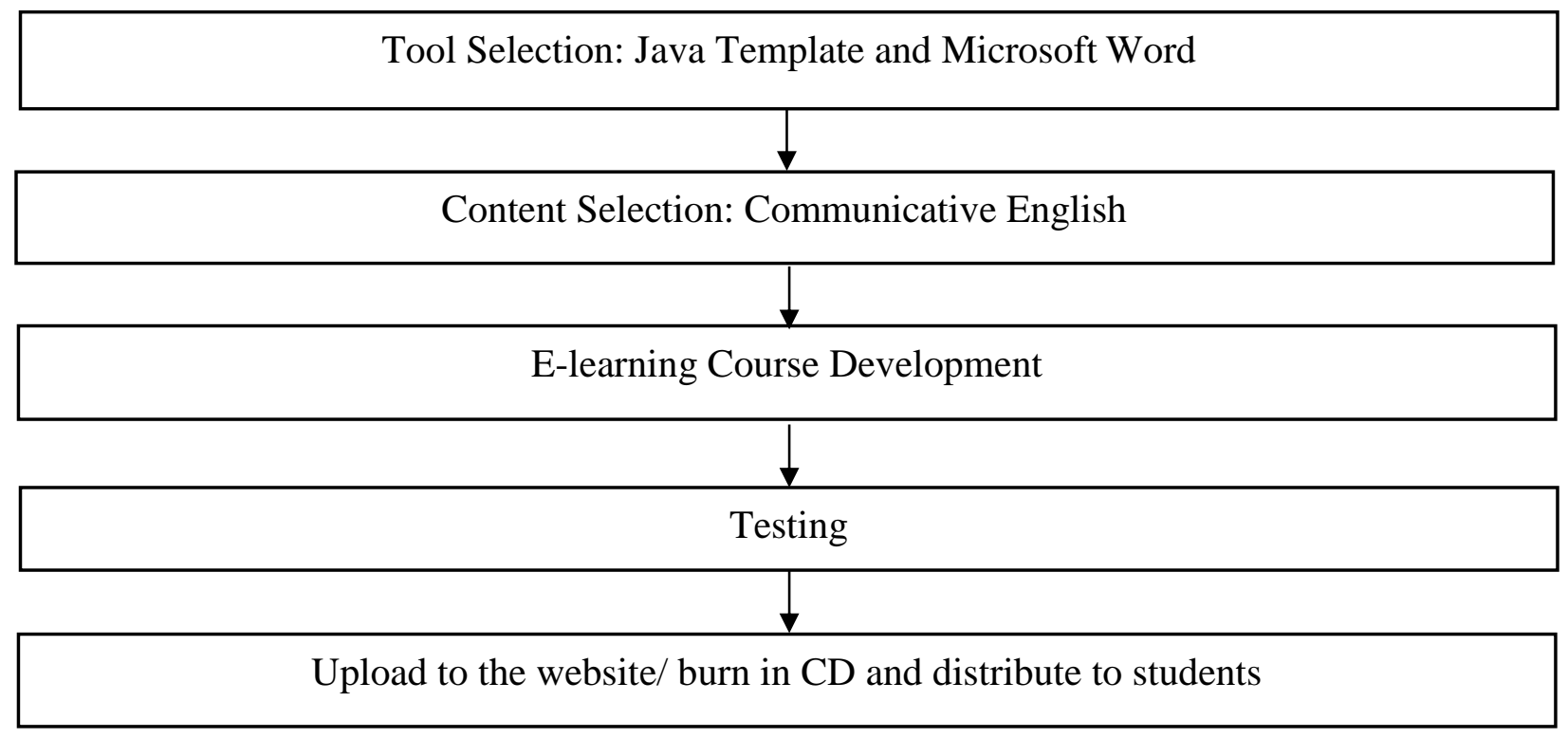

Figure 1: The Stages Of E-Learning Courseware Development (Source: Developed by The Authors) 


\section{Results and Discussion}

The following figures show the results of each e-learning courseware development stage. Each figure is captured using the print screen mode of the computer to show the on-screen stages involved. Firstly, the location of the file can be identified by opening the Jscript file using a notepad (see Figure 2). Here, the tree items, that is, the files of content are shown. For example, in this Communicative English courseware, there are four main files or main topics created, which are named "Topic 1", “Topic 2", "Topic 3" and "Contact Us" (see Figure 2). Under these main files, the sub-files or subtopics are created. For instance, under the main file "Topic 1", the sub-files or subtopics created are Introduction, 1.1, 1.2, Assessment, and Summary. In addition, the location or the order of each main and sub-files can be modified and the changes would be updated automatically when the notepad is saved. Hence, when the users click on "Topic 1", the list of content or related sub-topic would appear by the saved content in the Jscript file. These Jscript files help to ease the content development process as it gives an overview of the content created as well as the files created (i.e., the main and sub files).

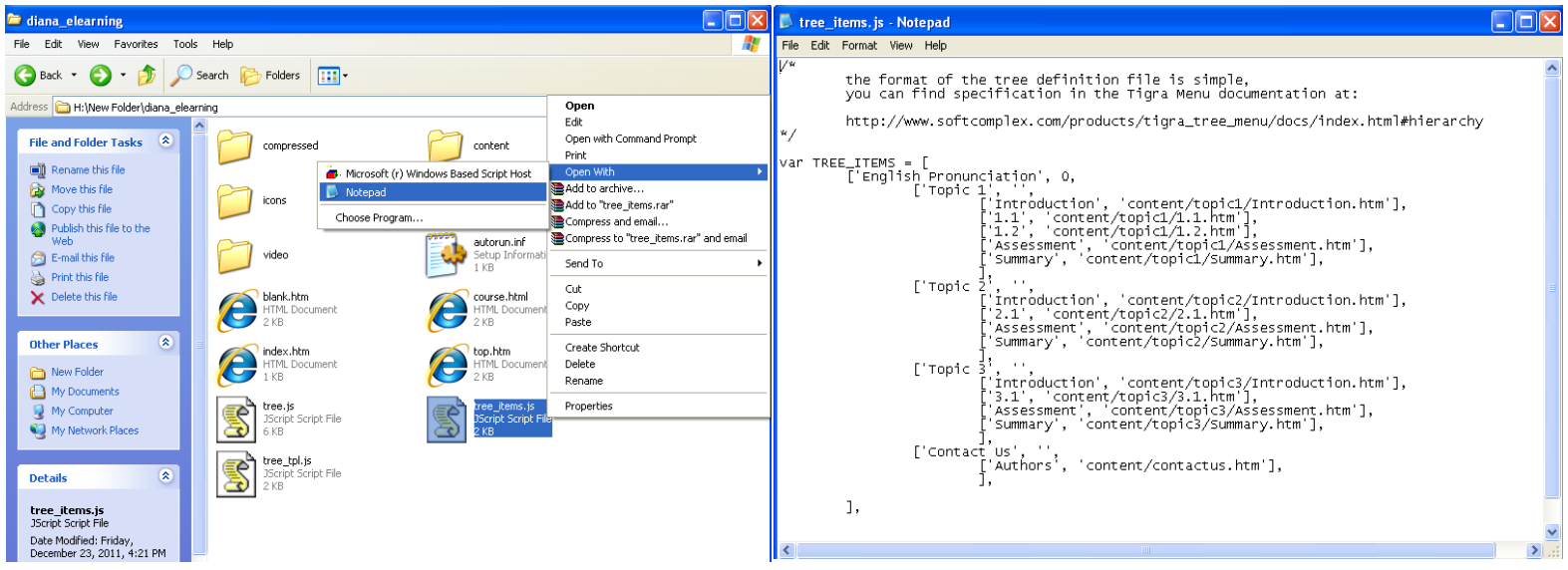

Figure 2: Jscript File Editing Using Notepad

(Source: Developed by The Authors)

Next, the content of the e-learning courseware is developed using MS Word software. The word files created are saved as .html instead of .doc files as can be seen in Figure 3. The content of the e-learning courseware content can be edited offline at any time using MS Word. Hence, instead of double click the .doc file which will open the file in web layout, a developer needs to right-click and open using MS Word as shown in Figure 3. All the editing or changes are needed to be saved as .html. Figure 4 shows one of the samples of content created for Communicative 
English e-learning courseware. The content in the web layout can be previewed by opening the .html files and any changes to the content can be previewed by just clicking the 'refresh' button.

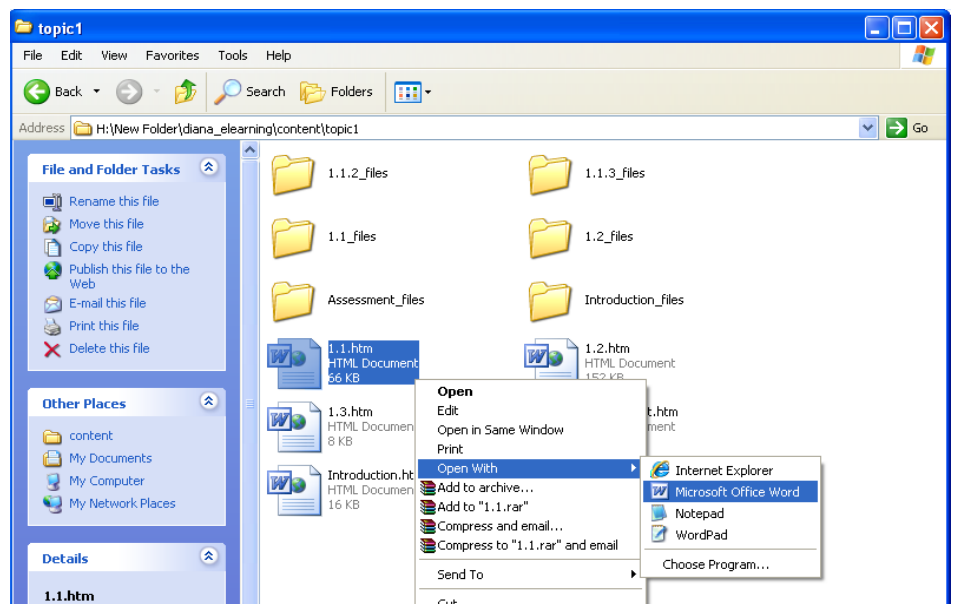

Figure 3: Content Files Editing Using Microsoft Word

(Source: Developed by The Authors)

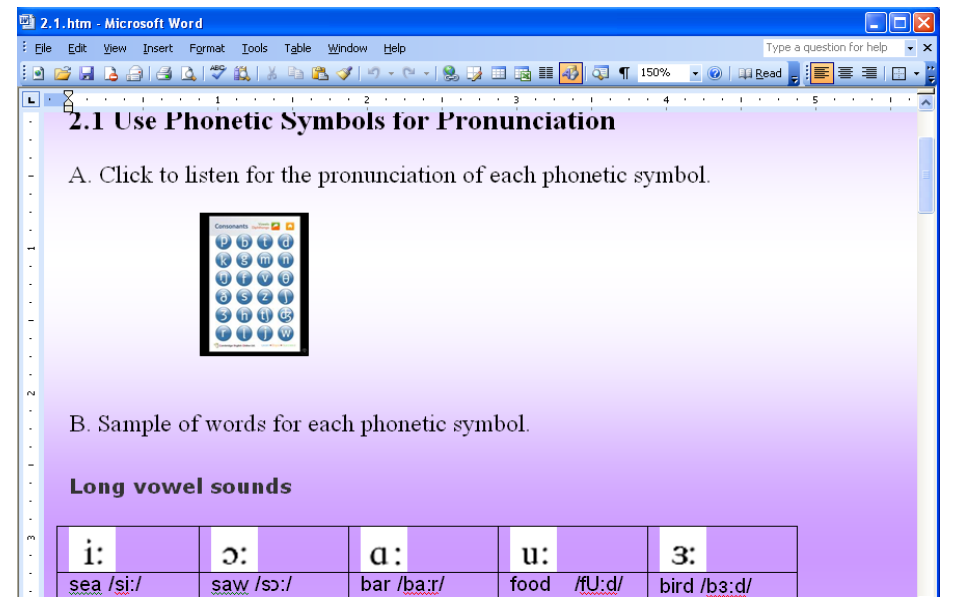

Figure 4: Sample of Content Development Using Microsoft Word (Source: Developed by The Authors)

Finally, the developed e-learning content is test-run to check for broken links and preview the actual appearance of the e-learning courseware on a web layout. Here, the index.htm file is opened using internet explorer and the message "Allow Blocked Content" would appear due to the security settings as shown in Figure 5. This can be resolved by enabling "Allow Blocked Content" as shown in Figure 5. To avoid the same pop-up message in the future, the internet security setting may be reset by enabling "Allow active content to run in files on My Computer" under the Internet options menu. 


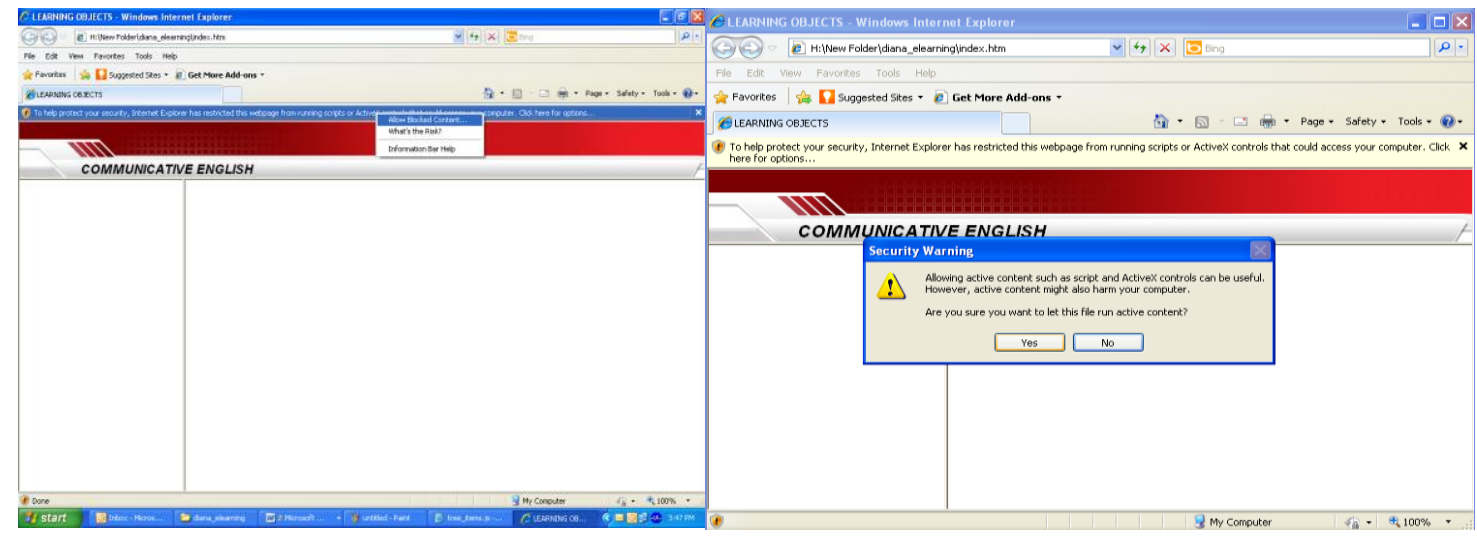

Figure 5: Security Setting During A Test Run of the .html Files

(Source: Developed by The Authors)

The sample of the result of the developed Communicative English e-learning courseware is shown in Figure 6. In this e-learning courseware, there are 4 main files created with linked subfiles as discussed earlier. For instance, a drop-down list of sub-files with active links would appear with a click on the main file "Topic 1" as shown in Figure 6. The content of each file created would appear on the right side of the web layout when the selected file is clicked. Hence, in this test run process, each file created would be tested to ensure no broken link and with the correct content.

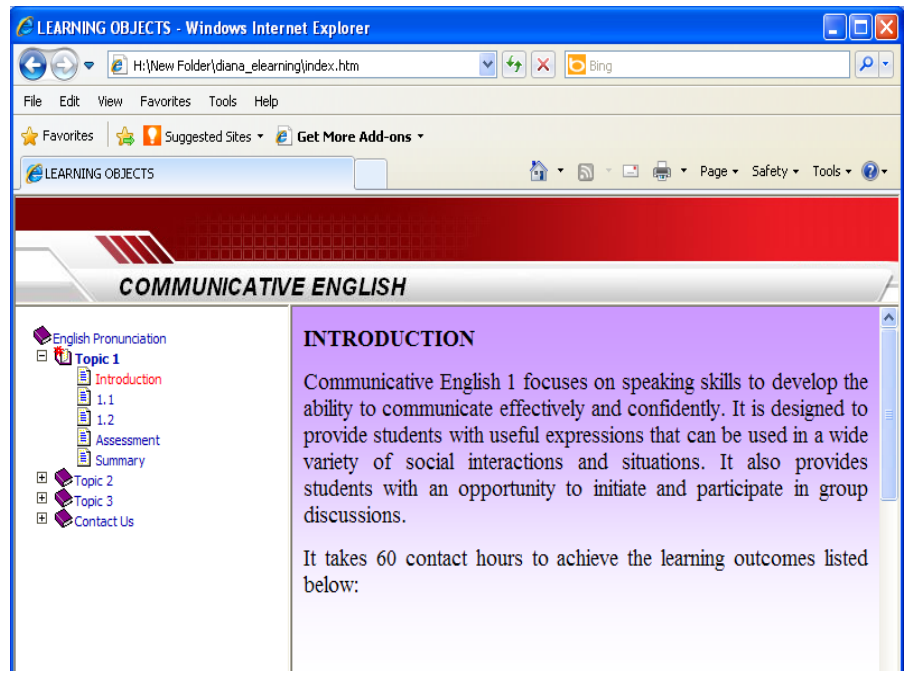

Figure 6: Sample of End Result of the Developed .html Files on The Web (Source: Developed by The Authors)

Figures 7 and 8 show the comparison of content created using MS Word and the actual outcome of the content and files created by using Jscript, respectively. The contents created using MS Word would be reflected the same on a web layout. The developed e-learning courseware can 
be published on the World Wide Web (WWW) by moving the files to a web directory or domain and students may easily get access to the content by using the URL link provided by the educators. Besides that, educators may share the developed e-learning courseware through available USB gadgets such as pen drive or thumb drive.

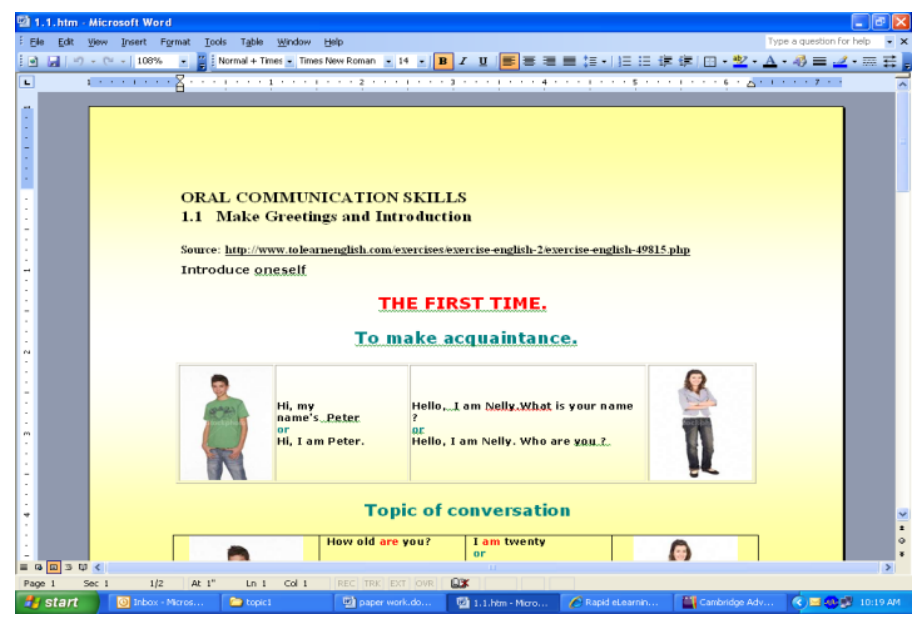

Figure 7: Content in .doc file (Source: Developed by the authors)

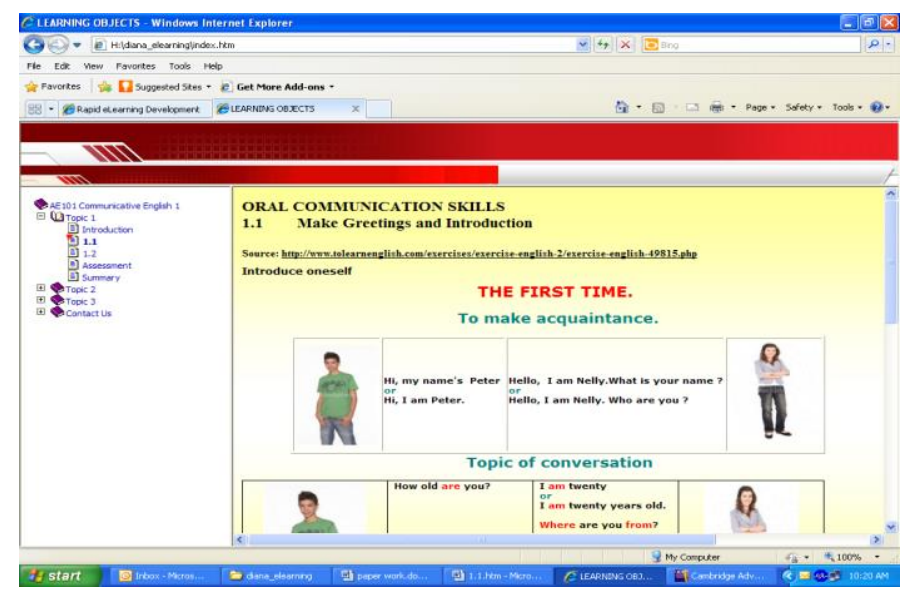

Figure 8: Content in .html file

(Source: Developed by the authors)

In general, the e-learning courseware development process is simple yet effective. This is because the educators (i.e., the prospect developer) are just required to make use of the java template which consists of Jscript files and MS Word to create their e-learning courseware. Besides, it is cost-effective because the development of this e-learning courseware does not require the educators to spend on authoring software but use the installed Microsoft Word Office instead. This new approach would be suitable for educators who are familiar with the use of MS Word but 
with limited IT knowledge or find that learning a new authoring software or application would be a burden to create their e-learning courseware.

To pilot test, the approach, three lecturers from Civil Engineering Department have applied this approach in creating their e-learning courseware for Geomatics, Building Structure, and Hydraulic subjects. Overall, the three lecturers gave positive feedback on the easiness to use this approach in creating their e-learning courseware as they are familiar with using Microsoft Word. Moreover, the lecturers stated that they can save more time as they usually use MS Word and PowerPoint to prepare their teaching materials. Hence, they can easily transfer the teaching materials in developing the e-learning courseware. In addition, one of the lecturers stated that he did not need to upload the teaching materials on Curriculum Information Document Online System (CIDOS) - a platform used by Malaysian polytechnic's lecturers to share documents or teaching materials as the students can easily retrieve the materials and information through the developed courseware. This is because students usually have to scroll and search for the documents and teaching materials either in the form of .doc, .ppt, .pdf, or videos uploaded by lecturers. By using this approach, the information was organized and the web-like appearance would make it easier for students to search for the information with a click on the active button or link in the e-learning courseware. Moreover, the lecturers gave an overview that this approach is good to build simple e-learning courseware and the courseware need to be linked with other applications such as Quizizz, Kahoot, Padlet, etc. to engage students and make the learning more interesting.

\subsection{Limitations}

In today's digital world, there is always pro and con and no one size fit all as far as software and application created by human are concerned. Here, the main tool in developing the e-learning courseware content is Microsoft Word Office, hence, the educators would be limited with the functions and features provided by this word processing program. However, this is not an issue as the basic functions and features provided by MS Word are more than enough to create interesting and engaging content. For instance, the creation of content from text to images as well as videos from a variety of online sources and links for quick access to webpages and files are all well supported by this word processing system. Therefore, though MS Word may not have the rich features of Macromedia Flash in creating animation or Dreamweaver in creating a website, educators may use the existing "insert", "link" or "save as" features provided in MS Word to add in existing animation and link to existing websites or videos as well as convert the word document 
to web-supported html files. Hence, educators do not have to spend on purchasing authoring software or application in creating their e-learning courseware.

Apart from that, another limitation for the e-learning courseware development would be the educators' creativity in creating interesting and engaging learning content. Here, educators' ability to reimagine and redesign the teaching and learning content is crucial to catch today's millennial generation. As students nowadays are techno-savvy and have diverse exposure in today's digital world, hence, it would be a challenge for educators to arouse students' interest and motivation to learn as well as engage them in the teaching and learning process. Thus, despite the available supported features provided in creating e-learning courseware, creativity is one of the crucial elements in creating a rich online lesson that helps students to be creative and innovative as well motivated to learn new things for betterment in various aspects.

Despite the limitations discussed earlier, that is, some limits on functions and features of MS Word and educators' creativity, this innovative yet simple method is the main concept proposed in this study. Instead of using more complex authoring software, simple and common software is used to help the inexperienced educators to create their e-learning content in a familiar environment without any hassle and the only difference would be their creativity in designing engaging content for their students. For that reason, this approach is a good bet for educators to start creating and developing their e-learning courseware.

\section{Conclusion}

The impact of pandemic Covid-19 has resulted in full online teaching and learning, thus the demand for e-learning courseware development arises. The proposed e-learning courseware development approach is inclined towards innovation in this 21 st century to help educators who have no experience or knowledge in developing e-learning courseware. This is a great method because it is easy to use and requires a short period in the development process based on individual preferences of the courseware's outcome. Therefore, this user-friendly method would be a good choice to start with regardless of the limitation discussed earlier. As Microsoft Word is not an authoring software, thus the developed courseware may not be as advanced as another developed e-learning courseware. As for future research, it is suggested that this approach be applied by not only polytechnic lecturers but also by school teachers or university educators. Besides the 
educational field, this approach could be applied in other fields of study and also for those who need a simple solution in courseware development.

\section{REFERENCES}

Donelly, R., \& McSweeney, F. (2009). Applied E-learning and E-teaching in higher education. New York: Information Science Reference. https://doi.org/10.4018/978-1-59904-814-7

Hao, Z., \& Li, Y. (2017). Use Microsoft office components and Database to quickly build a lightweight website. Proceedings of the 2017 International Conference on Management Engineering, Software Engineering and Service Sciences, 173 - 176. https://doi.org/10.1145/3034950.3035010

Hirumi, A. (2002). A Framework for Analysing, Designing, and Sequencing Planned e-learning Interactions. Quarterly Review of Distance Education 3(2), 141-160. Retrieved from https://eric.ed.gov/?id=EJ654229

Hoq, M. Z. (2020). E-learning during the period of pandemic (COVID-19) in the Kingdom of Saudi Arabia: An empirical study. American Journal of Educational Research, 8(7), 457 464. DOI:10.12691/education-8-7-2. Retrieved from http://article.scieducationalresearch.com/pdf/education-8-7-2.pdf

Horton, W. \& Horton, K. (2003). E-Learning Tools and Technologies. Wiley Publishing, Inc.: Canada. Retrieved from https://www.wiley.com/en-us/9780471444589

Jayachithra, J. (2020). Information and communication technology in teaching and learning: Perspective on e-learning at the higher education level. International Journal of Recent Technology and Engineering (IJRTE), 8(5), 4084-4086. https://doi.org/10.35940/ijrte.E6697.018520

Kpakiko, M. M., Abdulhamid, M., \& Saidu, S. (2021). Utilization of e-learning: A tool for social and collaborative teaching and learning in the era of a pandemic. Proceeding of the $1^{\text {st }}$ LISVN International Conference, 342-380. http://repository.futminna.edu.ng:8080/jspui/handle/123456789/7198

Luo Y.W. (2010). Using JavaScript to implement real-time feedback in online learning. Journal of Engineering Technology and Education, 7(1), 16-20. Retrieved from http://ir.lib.kuas.edu.tw/bitstream/987654321/10022/2/18133851-201003-201004230090201004230090-16-20.pdf 
Marriott de Cassia, R. \& Torres, P.L. (2009). Handbook of Research on E-Learning Methodologies for Language Acquisition. New York: Information Science Reference. https://doi.org/10.4018/978-1-59904-994-6

Melia, M. \& Pahl, C. (2009). Constraint-Based Validation of Adaptive e-Learning Courseware. IEEE Transactions on Learning Technologies, 2(1), 37 - 49. https://doi.org/10.1109/TLT.2009.7

Moore, K., (2007). Keeping the e-Learning Strategy Focused. In Brandon, B. (Ed.), The eLearning Guild's Handbook of e-Learning Strategy (pp. 2-9). The eLearning Guild: Santa Rosa, CA. Retrieved from https://theelearningcoach.com/wpcontent/uploads/downloads/2010/06/strategy_ebook.pdf

Shaaban, S. S. A. (2020). TEFL Professors' e-learning experiences during the Covid 19 pandemic. European Journal of Foreign Language Teaching, 5(1), 82-96. https://doi.org/10.46827/ejfl.v5i1.3202

Sadashiv, N. A. \& Prakash, N. K. (2016). Designing and developing multilingual support for web development for Indian languages. International Journal of Innovations in Engineering Research and Technology. 3(6), 52-60. Retrieved from https://repo.ijiert.org/index.php/ijiert/article/download/899/855/1711

Wolfe, C.R. (1992). Using Authorware Professional for developing courseware. Behaviour Research Methods, Instruments \& Computers, 24(2), 273-276. https://doi.org/10.3758/BF03203507 